\title{
Toughening of Aluminum Hydroxide Filled Acrylic Composite
}

\author{
Hiroshi MASAOKA*, Shigeo KOHMOTO*, and Makoto YAMAMOTO*
}

\begin{abstract}
The microscopic study suggested that the destruction of aluminum hydroxide filled acrylic composite proceeded inside of the particle. Therefore, the protection of the brittle particle from the cleavage was important for toughening of this system. This purpose was achieved by addition of newly prepared carboxyl terminated unsaturated polyesters having flexible segment to the composite. These polyesters contained both carboxyl and vinyl groups, therefore they were absorbed selectively by the basic surface of aluminum hydroxide and gave the elastic layer by crosslinking. In addition, these modifiers were copolymerized with the matrix acrylic resin, and hence the strong adhesion between the elastic layer and the matrix toughened the composite more effectively. Consequently, this work provided the concept for toughening of aluminum hydroxide filled acrylic composite, and proposed an efficient toughening method.

The effect of these impact modifiers was detected at the fracture surface of the composite and characterized by scanning electron microscope (SEM) observation and elemental analysis which were given by energy-dispersed X-ray micro-analyzer equipped with the SEM (SEM-EDX analysis).
\end{abstract}

\section{Introduction}

As an application of the particle reinforced composite materials, the "artificial marble" has become popular as interior parts of buildings ${ }^{1-3)}$. These are often combined with pigments and granules and used as raw materials for a worktop and a washbowl.

Though the unsaturated polyester was launched as the matrix resin for the composite, the acrylic resin becomes popular for its superior appearance, and environmental and chemical resistances ${ }^{4}$.

Inorganic particle such as aluminum hydroxide, silica and calcium carbonate gives hardness and heat resistance to the matrix resin, but the toughness of these composites is usually not good enough and the glass fiber reinforced backing is generally attached.

We proposed the effective toughening method of sil-

\footnotetext{
* Graduate School of Science and Technology,

Chiba University,

1-33 Yayoi-cho, Inage-ku, Chiba 263-8522, Japan

(Received : April 20, 2000)
}

ica filled acrylic composite, and concluded that the silica/matrix interfacial adhesion was important factor for the toughening of this system ${ }^{5}$.

This article describes the characteristics in destruction of aluminum hydroxide filled acrylic composite and introduces the effective toughening method. Aluminum hydroxide is particularly important for the products of artificial marble, because the powder makes the composite suitable for processing by machine tools.

\section{Experimental}

\subsection{Measurement}

IZOD impact strength was measured by IZOD IMPACT TESTER (Toyoseiki Co.).

Flexural and tensile properties were obtained by Tensilon RTC-1325A (Orientec Co.).

SEM micrographs and images of SEM-EDX analysis were taken by field emission scanning electron microscope S800 (Hitachi Ltd.) equipped with energydispersed X-ray micro-analyzer KEVEX 8000 (Kevex Co.).

Number-average molecular weight was measured 
by gel permeation chromatography HPLC8020 (Toso Co.,Ltd).

The acid value was obtained by titration with $0.1 \mathrm{~mol} / 1 \mathrm{KOH}$ ethanolic solution.

\subsection{Materials}

Poly(methyl methacrylate) (PMMA) having Mn 120,000 were obtained from ICI Ltd.

Aluminum hydroxide dry powder having $12 \mu \mathrm{m}$ in average particle size was obtained from Martinswerk GmbH.

VTBN $1300 \times 33$ (methacryloyl terminated butadiene/acrylonitrile copolymer) and CTBN $1300 \times 31$ (carboxyl terminated butadiene/acrylonitrile copolymer) liquid elastomers were obtained from B.F. Goodrich Co. .

Liquid polyester diol, poly[(3-methyl-1,5pentandiol)-alt-(adipic acid)] having Mn 2000 was obtained from Kuraray Co., Ltd.

Hydroxyl terminated liquid polybutadiene having Mn 2800 was obtained from Idemitsu Petrochemical Co.,Ltd.

Methyl methacrylate (MMA), stearic acid, maleic anhydride, toluene, $p$-methoxyphenol, and $p$ toluenesulfonic acid (monohydrate) were obtained from Kanto Chemicals Co., Inc., and $t$-butyl peroxy 2ethylhexanoate (Kayaku AKZO Co.) was used as received.

\subsection{Synthesis of carboxyl terminated unsaturated polyester resin}

Synthesis of carboxyl terminated unsaturated polyester (A)

Poly [(3-methyl-1, 5-pentandiol)-alt-(adipic acid)] $(223.6 \mathrm{~g})$, maleic anhydride $(16.4 \mathrm{~g})$, toluene $(160.0 \mathrm{~g})$, and p-toluenesulfonic acid $(0.4 \mathrm{~g})$ were poured into $500 \mathrm{ml}$ flange flask equipped with stirrer, thermometer and distilling trap, and the mixture was refluxed for $6 \mathrm{hr}$ under nitrogen flow. The reaction water was removed through the distilling trap. The reaction mixture was cooled and residual toluene was removed by distillation under reduced pressure.

Then clear pale yellow solid (A) having Mn 4100 and acid value $35 \mathrm{mg} \mathrm{KOH} / \mathrm{g}$ was obtained. The expected structure of this polyester resin (A) is described in Figure 1.
C-R $-\mathrm{CO}\left[\left(\mathrm{O}-\mathrm{R}_{2}-\mathrm{OCO}-\mathrm{R}_{3}-\mathrm{COO}\right)_{\mathrm{m}}-\mathrm{R}_{2}-\mathrm{OCO}-\mathrm{R}_{\mathbf{1}}-\mathrm{COO}\right]_{\mathrm{n}}-\mathrm{H}$ $\mathrm{R}_{1}$ : $-\mathrm{CH}=\mathrm{CH}-, \mathrm{R}_{2}$ : $-\left(\mathrm{CH}_{2}\right)_{2}-\mathrm{CH}\left(\mathrm{CH}_{3}\right)-\mathrm{CH}_{2^{-}}, \mathrm{R}_{3}:-\left(\mathrm{CH}_{2}\right)_{4^{-}}$
(A): $\mathbf{m} \doteqdot 9, \mathbf{n} \doteqdot \mathbf{2}$
(B): $\mathbf{m} \doteqdot 9, \mathbf{n} \doteqdot 4$

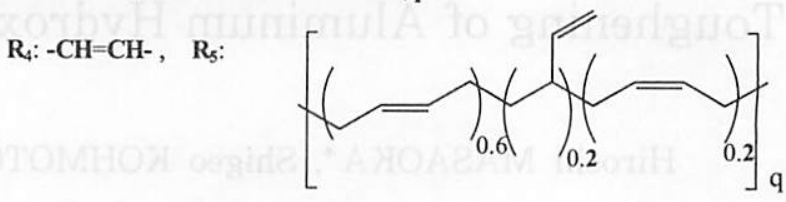

(C): $\mathrm{p} \div 2, \mathrm{q} \div 50$

Fig. 1 Structure of carboxyl terminated unsaturated polyester (A) $-(\mathrm{C})$

Synthesis of carboxyl terminated unsaturated polyester (B)

Unsaturated polyester (B) having Mn 6700 and acid value $9.9 \mathrm{mg} \mathrm{KOH} / \mathrm{g}$ was obtained by the same procedure as described in polyester (A) synthesis from poly [(3-methyl-1, 5-pentandiol)-alt-(adipic acid)] (226.2g), maleic anhydride $(13.9 \mathrm{~g})$, toluene $(160.0 \mathrm{~g})$, and p-toluenesulfonic acid $(0.2 \mathrm{~g})$. The expected structure of $(\mathrm{B})$ is described in Figure 1.

Synthesis of carboxyl terminated unsaturated polyester (C)

Unsaturated polyester (C) having Mn 6100 and acid value $27 \mathrm{mg} \mathrm{KOH} / \mathrm{g}$ was obtained by the same procedure as described in polyester $(\mathrm{A})$ synthesis from hydroxyl terminated liquid polybutadiene(228.0g), maleic anhydride( $12.0 \mathrm{~g})$, toluene $(160.0 \mathrm{~g})$, and ptoluenesulfonic acid $(0.4 \mathrm{~g})$. The expected structure of (C) is described in Figure 1.

\subsection{Preparation of acrylic composite} Preparation of aluminum hydroxide filled acrylic composite (1) as the control

MMA (182g), PMMA (18g) and p-methoxyphenol (18mg) were poured into $1 \mathrm{~L}$ flange flask equipped with stirrer, thermometer and condenser. The mixture was stirred for $1 \mathrm{hr}$ at $50^{\circ} \mathrm{C}$ for dissolving PMMA then cooled to ambient temperature. Aluminum hydroxide powder $(600 \mathrm{~g}), t$-butyl peroxy 2ethylhexanoate $(10.0 \mathrm{~g})$ as the hardener and stearic acid $(1.0 \mathrm{~g})$ as the mold release agent were added and stirred further $1 \mathrm{hr}$, then viscous dispersion (D) was obtained.

This catalyzed dispersion (D) was placed in the flat mold lined with stainless plate, and heated $1 \mathrm{hr}$ at 60 
${ }^{\circ} \mathrm{C}$ then $1 \mathrm{hr}$ at $90^{\circ} \mathrm{C}$, then obtained the sheet of acrylic composite (1).

Preparation of VTBN liquid elastomer modified acrylic composite (2)

VTBN $1300 \times 33(25 \mathrm{~g})$ was dissolved in $475 \mathrm{~g}$ of dispersion(D) and obtained the sheet of acrylic composite (2) by the same procedure as described in composite (1) preparation. This composite contained $5 \mathrm{wt} \%$ of VTBN polymerisable liquid elastomer.

Preparation of CTBN liquid elastomer modified acrylic composite (3)

The acrylic composite (3) contained $5 \mathrm{wt} \%$ of CTBN $1300 \times 31$, carboxyl terminated saturated liquid elastomer, was obtained by the same procedure as described in composite (1) preparation.

Preparation of carboxyl terminated polyester (A) modified acrylic composite (4)-(7)

The polyester (A) modified acrylic composites (4)(7) were obtained by the same procedure as described in composite (1) preparation. These formulations contained 1.0, 2.0, 3.0, and $4.0 \mathrm{wt} \%$ of polyester (A), respectively.

Preparation of carboxyl terminated polyester (B) modified acrylic composite (8)-(12)

The polyester (B) modified acrylic composites (8)(12) were obtained by the same procedure as described in composite (1) preparation. These formulations contained $0.5,1.0,2.0,3.0$, and $4.0 \mathrm{wt} \%$ of polyester (B), respectively.

Preparation of carboxyl terminated polyester (C) modified acrylic composite (13) - (15)

The polyester (C) modified acrylic composites (13)(15) were obtained by the same procedure as described in composite (1) preparation. These formulations contained $1.0,2.0$ and $3.0 \mathrm{wt} \%$ of polyester $(\mathrm{C})$, respectively.

The amount of impact modifiers (A)-(C) in the acrylic composite (4)-(15) is summarized in Table 1.

Table 1 Impact modifiers (wt\%) in comsite (4)-(15)

\begin{tabular}{c|c|c|c|c|c|c|c|c|c|c|c|c}
\hline Modifier & $(4)$ & $(5)$ & $(6)$ & $(7)$ & $(8)$ & $(9)$ & $(10)$ & $(11)$ & $(12)$ & $(13)$ & $(14)$ & $(15)$ \\
\hline (A) & 1.0 & 2.0 & 3.0 & 4.0 & - & - & - & - & - & - & - & - \\
\hline (B) & - & - & - & - & 0.5 & 1.0 & 2.0 & 3.0 & 4.0 & - & - & - \\
\hline (C) & - & - & - & - & - & - & - & - & - & 1.0 & 2.0 & 3.0 \\
\hline
\end{tabular}

\subsection{Preparation of carboxyl terminated polyester-MMA copolymer (16)-(18)}

The carboxyl terminated polyesters $(\mathrm{A})-(\mathrm{C})$ were dissolved in MMA and prepared 50wt\% solution, respectively. Each MMA solutions were catalyzed by $1 \mathrm{wt} \%$ of $t$-butyl peroxy 2-ethylhexanoate and cured at $90^{\circ} \mathrm{C}$ for $1 \mathrm{hr}$ in the flat mold lined with PET film, then transparent acrylic sheets (16)-(18) were obtained.

\subsection{Testing}

The obtained sheets of acrylic composite were provided for property measurement.

IZOD impact strength, and flexural modulus were measured for characterization of mechanical properties.

The destruction phase obtained by IZOD impact test was characterized by SEM observation and SEMEDX analysis.

The sheets of carboxyl terminated polyester-MMA copolymers were used for measurement of tensile properties.

\section{Result and Discussion}

Table 2 gives the effect of VTBN and $\mathrm{CTBN}^{6-8)}$ on IZOD impact strength and flexural modulus of the aluminum hydroxide filled acrylic composite. These two modifiers did not increase the destruction energy of the composite, while VTBN toughened the silica filled acrylic composite ${ }^{5}$.

Table 2 Impact strength and flexural modulus of comsite (1)-(3)

\begin{tabular}{c|c|c}
\hline Code & IZOD Impact strength & Flexural modulus \\
\hline$(1)$ & $4.25 \mathrm{~kJ} / \mathrm{m}^{2}$ & $8.39 \mathrm{GPa}$ \\
\hline$(2)$ & 4.17 & 8.24 \\
\hline$(3)$ & 2.19 & 6.26 \\
\hline
\end{tabular}

The effect of CTBN on the aluminum hydroxide filled composite was similar to that of silica filled acrylic composite and reduced both impact strength and flexural modulus, therefore CTBN behaved as a plasticizer in aluminum hydroxide filled system.

In order to investigate more about destruction mechanism of these composite, the fracture surface obtained by IZOD impact test 
was studied by SEM, in addition, by SEM-EDX analysis.

The SEM-EDX analysis is one of the convenient techniques of elemental analysis and gives qualitative and quantitative information of the existing elements at the very surface of the substrates. Therefore, this analysis is particularly useful for determi- nation of the destruction phase of the composite.

Figure 2 (a) of SEM micrograph is the crosssection of the fracture surface obtained from unmodified aluminum hydroxide filled acrylic composite (1) in low magnification $(\times 100)$. Figure $2(b)$ is aluminum mapping image given by the SEM-EDX analysis at the same position. Since the density of the
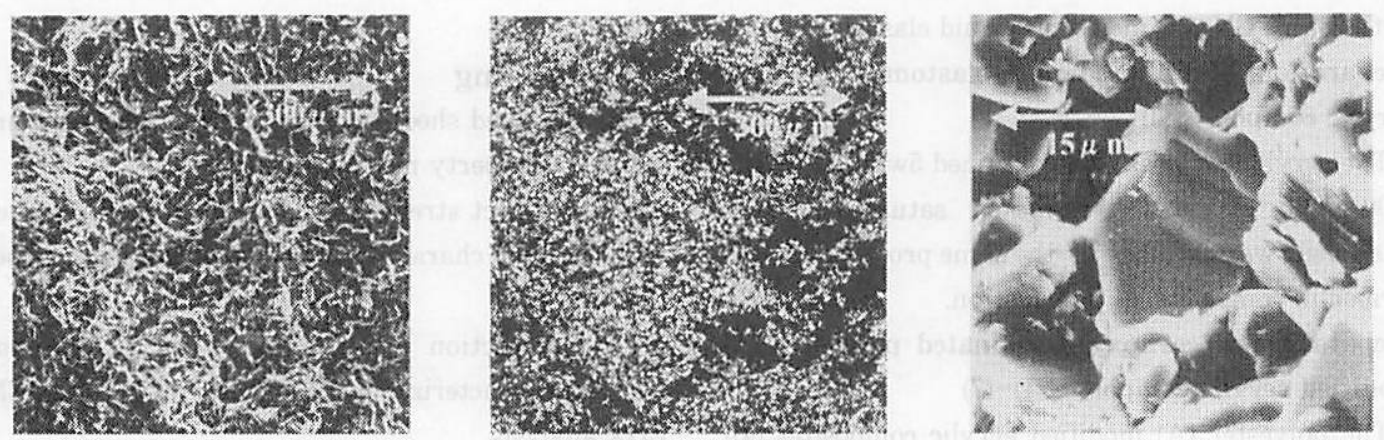

Fig. 2 (a) SEM micrograph at fracture surface of unmodified acrylic composite (1)

(b) SEM-EDX aluminum mapping image of Fig. 2 (a)

(c) SEM micrograph at fracture surface of composite (1) in higher magnification
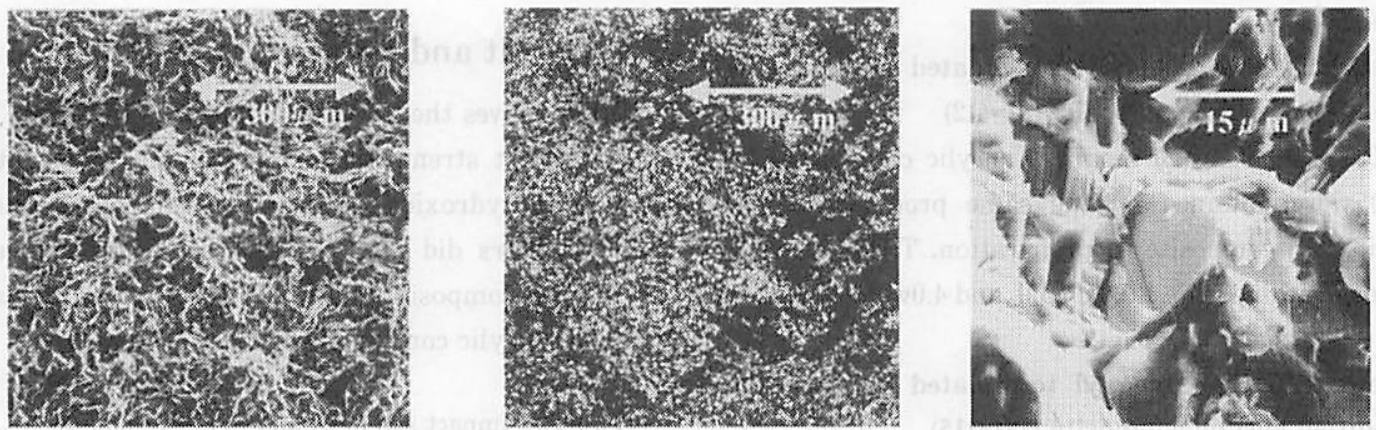

Fig. 3 (a) SEM micrograph at fracture surface of VTBN $5 w t \%$ modified acrylic composite (2)

(b) SEM-EDX aluminum mapping image of Fig. 3 (a)

(c) SEM micrograph at fracture surface of composite (2) in higher magnification
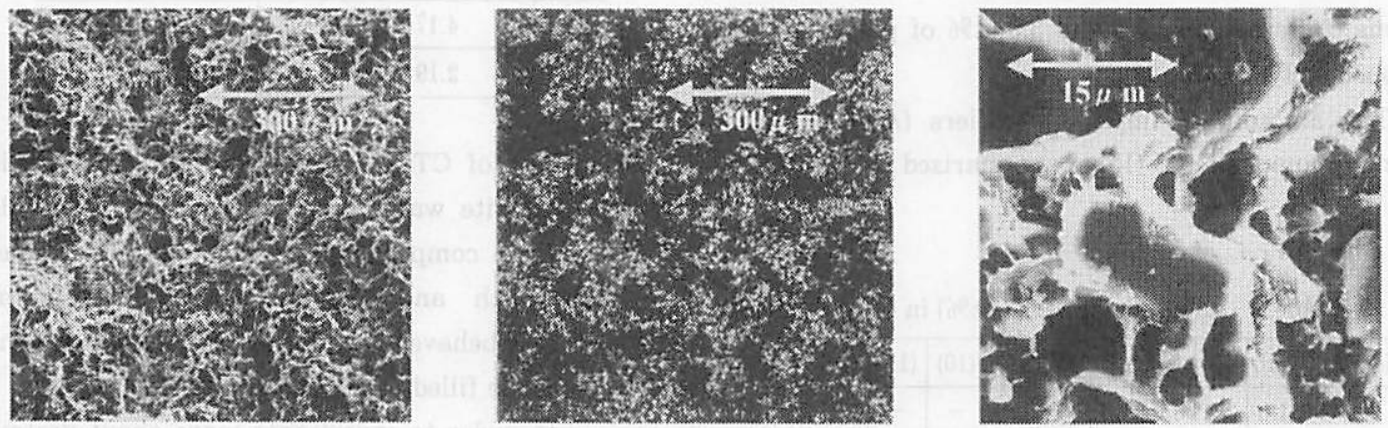

Fig. 4 (a) SEM micrograph at fracture surface of CTBN 5wt\% modified acrylic composite (3)

(b) SEM-EDX aluminum mapping image of Fig. 4 (a)

(c) SEM micrograph at fracture surface of composite (3) in higher magnification 
white dots describe the concentration of aluminum atom existing at the fracture surface, the destruction of the composite (1) was proceeded mainly at the filler /matrix interface or at the inside of the filler. Figure 2 (c) of SEM micrograph in higher magnification $(\times 2000)$ at the same position gives the evidence of the cohesive failure of the filler.

The aluminum hydroxide is known as a brittle particle and the fracture proceeded along the cleavage planes as shown in this figure.

Figures 3 (a)-3 (c) are given from 5wt\% VTBN1300 $\times 33$ modified acrylic composite (2). These three images are very similar to those of unmodified composite (1). Since the destruction was dominated by cleavage of aluminum hydroxide inside, it was reasonable that the improved adhesion in aluminum hydroxide /matrix interface gave little effect on both impact strength and flexural modulus ${ }^{5)}$.

In contrast, Figures 4 (a) -4 (c) from CTBN modified acrylic composite (3) gave the evidence of filler/matrix interfacial failure. Interestingly, CTBN liquid elastomer was observed at the surface of aluminum hydroxide in SEM micrograph of higher magnification.

The surface of aluminum hydroxide particle has basic character, thus the ionic absorption of the carboxyl groups in CTBN was quite reasonable. And this result led to an idea of toughening method for the aluminum hydroxide filled acrylic composite, that is, to generate the elastic layer around the particle by the selective absorption and crosslinking of carboxyl terminated unsaturated polyesters having relatively large soft segment. The polyesters (A)-(C) were designed for this purpose.

These modifiers were all prepared by one-step condensation polymerization. The difference in physical properties of these three was characterized indirectly by MMA copolymers (16)-(18). The tensile properties of these copolymers are summarized in Table 3.

The effect of the polyester (A) on impact strength and flexural modulus for
Table 3 Tensile properties of the unsaturated polyesterMMA copolymers

\begin{tabular}{c|l|c|c}
\hline Code & Modulus & Elongation & Yield strength \\
\hline$(16)$ & $250 \mathrm{MPa}$ & $27 \%$ & $8.5 \mathrm{MPa}$ \\
\hline$(17)$ & 165 & 65 & 6.1 \\
\hline$(18)$ & 38 & 15 & 3.2 \\
\hline
\end{tabular}

the composite was given by composite (4)-(7). Around $2 \mathrm{wt} \%$ addition of the modifier (A) gave the maximum impact strength, but the fracture energy was reduced by further modification. On the other hand, the flexural modulus was kept constant up to $2 \mathrm{wt} \%$ addition and then declined by the excess amount (Figure 5).

Therefore, it was obvious that the unsaturated polyester (A) was absorbed by the particle in the dispersion (D) up to $2 \mathrm{wt} \%$ and was formed the protec-

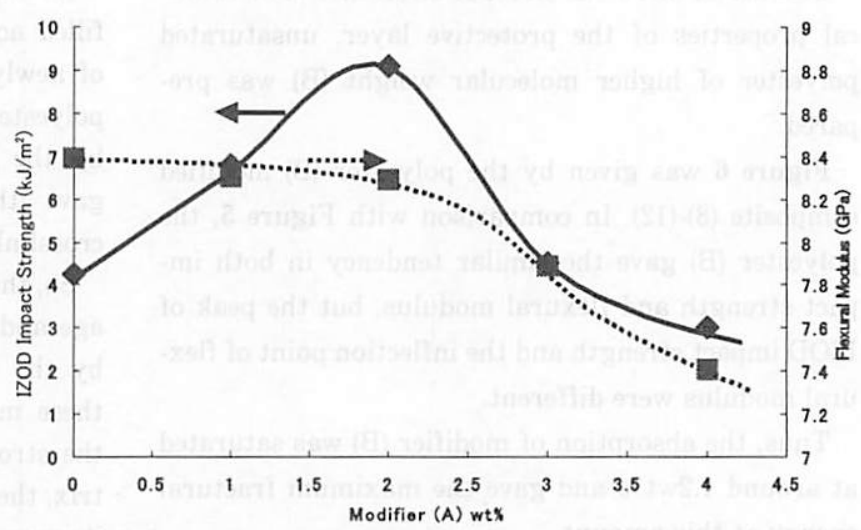

Fig. 5 Effect of modifier (A) on impact strength and flexural modulus of acrylic composite

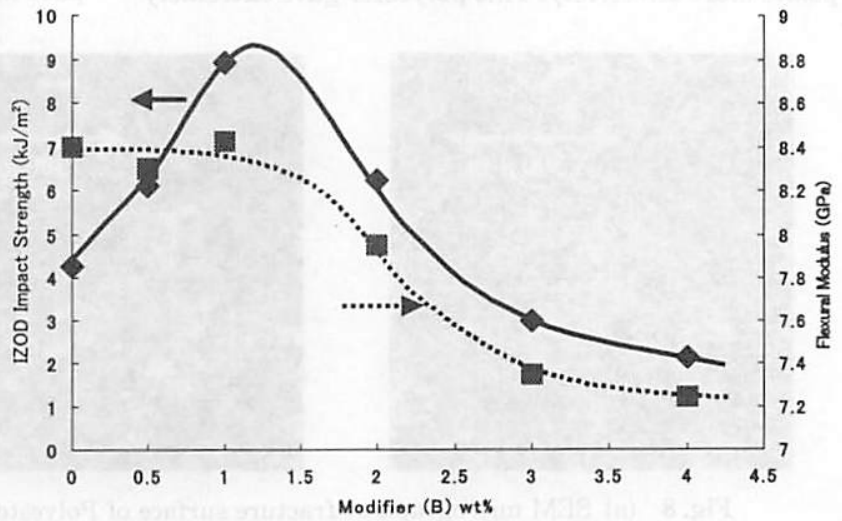

Fig. 6 Effect of modifier (B) on impact strength and flexural modulus of acrylic composite 


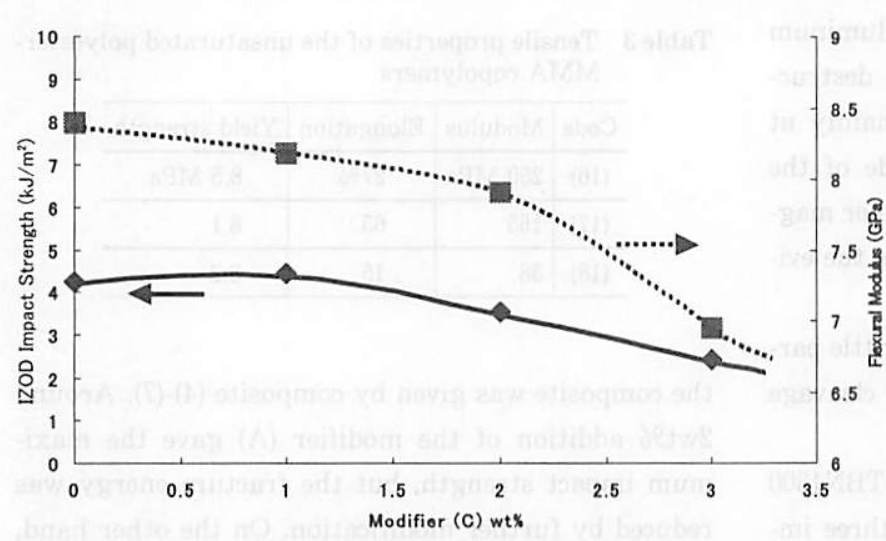

Fig. 7 Effect of modifier (C) on impact strength and flexural modulus of acrylic composite

soft layer (Table 2). But the result was against our expectation. Figure 7 suggested that the cured layer was too weak and brittle to absorb the destruction energy.

The microscopic observation of the toughened composite is shown in Figures 8 (a) -8 (c). These images were given from the fracture surface of $2 w t \%$ polyester (A) modified acrylic composite (5).

Aluminum mapping image (Figure 8 (b)) indicates that the fracture proceeded mainly inside of the resin. And SEM micrograph of higher magnification (Figure $8(\mathrm{c}))$ gives the evidence that the particle was protected from the cleavage by the

tive layer at curing of the composite. But the excess amount worked as the plasticizer, and both the modulus and the impact strength were reduced.

In order to know the effect of difference in mechanical properties of the protective layer, unsaturated polyester of higher molecular weight (B) was prepared.

Figure 6 was given by the polyester (B) modified composite (8)-(12). In comparison with Figure 5, the polyester (B) gave the similar tendency in both impact strength and flexural modulus, but the peak of IZOD impact strength and the inflection point of flexural modulus were different.

Thus, the absorption of modifier (B) was saturated at around $1.2 \mathrm{wt} \%$ and gave the maximum fractural energy at this amount.

Modifier (C) was designed for toughening the composite more effectively. This polyester gave extremely organic layer.

\section{Conclusion}

As all presented above, the aluminum hydroxide filled acrylic composite was toughened by addition of newly prepared carboxyl terminated unsaturated polyesters. These modifiers were absorbed ionically by the basic surface of aluminum hydroxide and gave the elastic layer around the particle by crosslinking.

So, the brittle particle was protected from the cleavage and the impact energy was absorbed effectively by the layer. In addition, the copolymerization of these modifiers with the matrix acrylic resin gave the strong adhesion between the layer and the matrix, therefore these modifiers toughened the composite synergistically.

We practically indicated that the ability of the impact modifier was closely related to the physical and
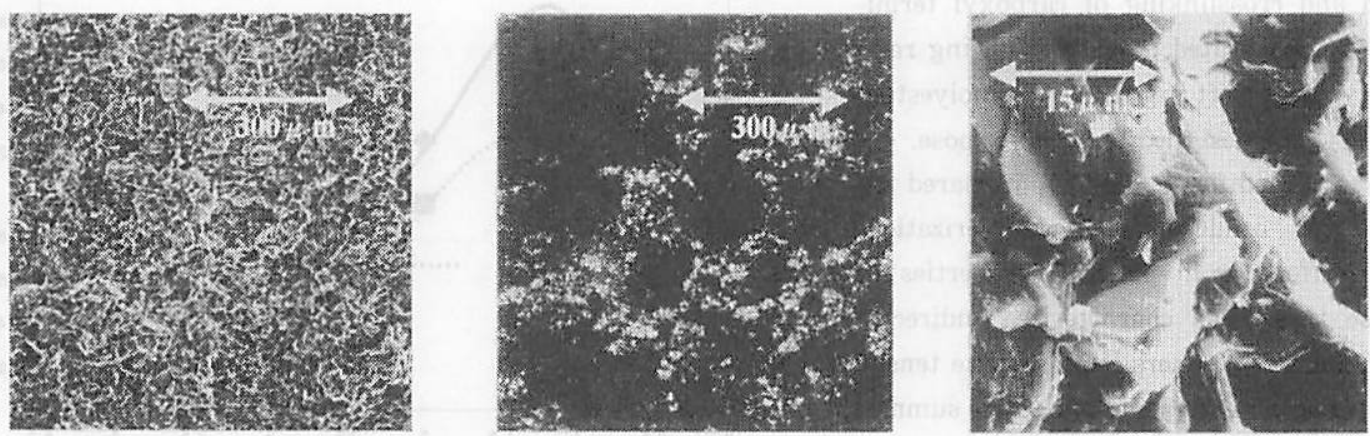

Fig. 8 (a) SEM micrograph at fracture surface of Polyester (A) 2 wt \% modified acrylic composite (5)

(b) SEM-EDX aluminum mapping image of Fig. 8 (a)

(c) SEM micrograph at fracture surface of composite (5) in higher magnification 
chemical properties of the modifiers, such as molecular weight, the structure of soft segment, and the content of carboxyl and vinyl groups. However, the structure of the modifier was not optimized through this work and the more efficient modifiers should be synthesized by further precise study.

Consequently, this work provided the concept for toughening of aluminum hydroxide filled acrylic composite, and proposed an efficient toughening method.

\section{Acknowledgment}

The authors wish to thank Ms. K Masaoka for her fine work in SEM and SEM-EDX analysis in this study.

\section{References}

1) V.A. Stayner, Prepr. Annu. Conf. Plast. Compos. Inst., 40, 19D, 1 (1985)

2) R. B. Seymour and R. D. Deanin (Ed.) "History of Polymeric Composites", VNU Science Press, Utrecht (1987)

3) D. R. Paul and S. Newman (Ed.), "Polymer Blend" vol. 2, Academic Press, New York (1978)

4) $\mathrm{GB} 1,493,393 \mathrm{~A}$

5) H. Masaoka, S. Kohmoto and M. Yamamoto, J. Adhes. Soc. Jpn., 36, 62 (2000)

6) N. C. Paul, D. H. Richards and D. Tompson, Polymer, 18, 975 (1977)

7) D. R. Egan and R. S. Drake, Construction \& Building Materials, 3, 208 (1989)

8) A. R. Siebelt, L. L. Tolle and R. S. Drake, Adhesive Age, July (1986)

\section{<論 文 >}

（受理 : 平成 12 年 8 月 23 日）

\section{水酸化アルミニウム充填アクリル系コンポジットの強䩲化 正岡 弘 ${ }^{*}$ 幸本 重男 $^{*} \cdot$ 山本 忠 $^{*}$}

水酸化アルミニウム粒子充填アクリル系コンポシットの強靭化を目的とし，シリカ充填系で効果の 見られた反応性液状ゴムによ変性を試みたが期待された結果は得られなかった。これは，破壊界面 の SEM 観察及び SEM-EDX 元素分析による解析結果から，該コンポジットの破壊が，水酸化アル ミニウム粒子内部の䢃開により支配されていることが原因であると考えられた。そこで，水酸化了ル ミニウム粒子の表面にマトリックス樹脂との親和性の高い弾性層を導入し，破壊エネルギーを吸収す る保護層とすれば，該コンポジットが効果的に強勒化されると考え添加剤の設計及び合成を検討した。 その結果, 末端にカルボキシル基を有し，さらに分子内にソフトセグメントを有する不飽和ポリエス テル樹脂が該コンポジットの耐衝撃強度を効率良く向上させることを見出した。本添加剂による強勒 化機構は含有するカルボキシル基が, 塩基性である水酸化アルミニウム粒子表面に選択的に吸着し, コンポジットの加熱硬化時に架橋し弾性層を形成すると同時にアクリル樹脂と共重合しその弾性層を マトリックス樹脂に強固に接着し破壊界面をマトリックス樹脂内部に移動したことによるものと考え られる。本報では人造大理石の原料として広く使用されている水酸化アルミニウムを充填したアクリ ル系コンポジットを強勒化するための基礎概念及び効率的な手段を提案する。

\footnotetext{
*千葉大学大学院自然科学研究科 